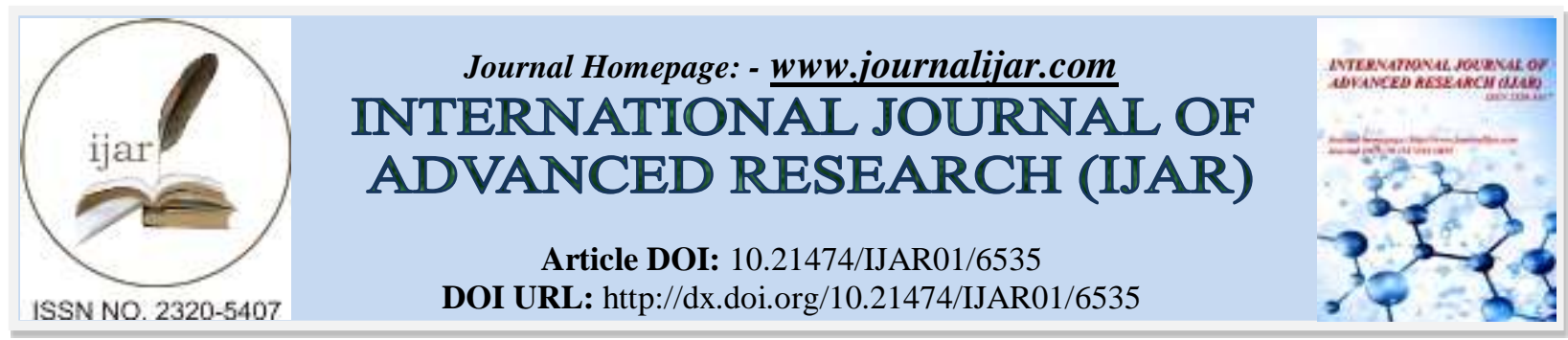

RESEARCH ARTICLE

\title{
DISTURBED MATERNAL IMMUNE MILIEU EARLY IN PREGNANCY COULD PREDICT LATER DEVELOPMENT OF PRE-ECLAMPSIA AND DIFFERENTIATE ITS SEVERITY GRADES.
}

Amr Sharafeldeen MD ${ }^{1}$ and Shaymaa M Abd El-Rahman MD ${ }^{2}$.

1. Departments of Obstetrics \& Gynecology, Faculty of Medicine, Benha University.

2. Medical Biochemistry, Faculty of Medicine, Benha University.

\section{Manuscript Info}

Manuscript History

Received: 14 December 2017

Final Accepted: 16 January 2018

Published: February 2018

Key words:-

Pre-eclampsia, Inflammatory

cytokines, Anti-inflammatory

cytokines, Severity prediction.

\section{Abstract}

Objectives: To estimate serum levels of tumor necrosis factor- $\alpha$ (TNF$\alpha$ ), interleukin (IL)- 6 and IL-10 in primigravida women at the $12^{\text {th }}$ week of gestation and to evaluate its predictability for later development and severity of pre-eclampsia (PE).

Patients \& Methods: The study included 130 primigravida women evaluated at the $12^{\text {th }}$ week gestational age clinically to assure being normotensive and gave blood samples for ELISA estimation of serum levels of TNF- $\alpha$, IL-6 and IL-10. All patients were evaluated 4-weekly for development of PE that was categorized as early or late and mild or severe.

Results: Sixty-five women developed PE; 23 early PE and 42 late; 47 mild and 18 severe PE. Serum TNF- $\alpha$ and IL-6 levels were significantly higher, while serum IL-10 levels were significantly lower in PE than control women with significantly higher IL-6/IL-10 ratio in PE women. ROC curve analysis defined high body weight, body mass index, high serum IL-6 and TNF- $\alpha$ and high IL-6/IL-10 ratio as significant specific predictor, while low serum IL-10 as a significant sensitive predictor for possibility of development of PE. Also, ROC curve analysis defined high IL-6/IL-10 ratio as significant sensitive predictor for severe PE, while defined high serum IL-6 and high TNF- $\alpha$ as significant specific predictors for mild PE.

Conclusion: Pre-eclampsia was associated with shift of immune response to pregnancy towards production of pro-inflammatory cytokines. The detected early disturbance of immune milieu points to its role in pathogenesis of PE. High IL-6/IL-10 ratio early in pregnancy could predict later development of PE especially severe PE. High IL-6 and TNF- $\alpha$ serum levels could early predict the development of mild PE.

Copy Right, IJAR, 2018,. All rights reserved.

\section{Introduction:-}

Pre-eclampsia (PE) is a pregnancy-specific disorder ${ }^{(1)}$ characterized by development of hypertension and proteinuria in a previously normotensive woman around or after the $20^{\text {th }}$ week of gestation ${ }^{(2)}$. Worldwide, PE affects $2-8 \%$ of all pregnancies ${ }^{(1)}$. PE is a life-threatening vascular disorder of pregnancy due to a failing stressed placenta ${ }^{(3)}$ and represents a significant health risk to both pregnant women and their unborn children ${ }^{(4)}$. 
Pregnancy is a unique physiological process that involves interplay of changes of hormonal and inflammatory milieu with cellular and molecular events at the maternal-fetal interface ${ }^{(5)}$. PE was considered as an autoimmune disorder

${ }^{(6)}$ developing secondary to pregnancy-induced hormonal and immunological changes through induction of local or systemic release of pro-inflammatory cytokines ${ }^{(7)}$. Pathogenesis of PE begins with abnormal cytotrophoblast apoptosis, which leads to inflammation and an increase in the levels of anti-angiogenic factors followed by disruption of the angiogenic status ${ }^{(8)}$.

Regulatory $\mathrm{T}$ (Treg) cells and $\mathrm{T}$ helper (Th) 17 cells are two distinct subsets of $\mathrm{CD} 4^{+} \mathrm{T}$ cells, which are mutually antagonistic in the immune response (IR) ${ }^{(9)}$. Regulatory $\mathrm{T}$ cells differentiate in the thymus, along with conventional CD4+ $\mathrm{T}$ cells to control homeostasis of the immune system and immune responses ${ }^{(10)}$. The CD3+, CD3+/CD4+, and $\mathrm{CD} 3+/ \mathrm{CD} 8+\mathrm{T}$-cell populations express intracellular cytokines including interferon-gamma, tumor necrosis factor- $\alpha$ (TNF- $\alpha$ ), interleukin (IL)-4 and IL-10 ${ }^{(11)}$.

Several types of $\mathrm{T}$ cells have been associated with the pathogenesis of pregnancy-induced complications ${ }^{(12)}$; changes of dendritic cells regarding phenotype and function change may be an important reason for PE through induction of immune imbalance ${ }^{(13)}$. Regulatory $\mathrm{T}$ cells are present at the fetal-maternal interface early in pregnancy and expand during pregnancy ${ }^{(14)}$.

Maternal serum screening for early predictors for development of PE is conducive to prompt gestational management, thus may improve pregnancy outcomes ${ }^{(15)}$, so the current study targets to estimate serum levels of pro-inflammatory cytokines; TNF- $\alpha$, IL- 6 and IL-10 as an anti-inflammatory cytokine in primigravida women at the $12^{\text {th }}$ week of gestation and to evaluate its predictability for development and severity of PE.

\section{Design:-}

Prospective selective comparative clinical trial

\section{Setting:-}

Benha University Hospitals

\section{Patients \& Methods:-}

The study protocol was approved by the Local Ethical Committee and all pregnant women fulfilled the inclusion criteria and agreed to attend the outpatient clinic for follow-up signed written fully informed consent. The study targets to collect $>60$ PE primigravida and then a similar number of primigravida women fulfilling the inclusion criteria and did not develop PE during the observation period were included as control group. All primigravida women with singleton fetus and attended the antenatal care unit prior to the $12^{\text {th }}$ week gestational age (GA) were eligible for evaluation for inclusion and exclusion criteria. At time of the $1^{\text {st }}$ visit all women underwent complete clinical and gynecological examination and GA was calculated since the $1^{\text {st }}$ day of the last menstrual period and confirmed by crown-rump length measurement on US examination.

Exclusion criteria included BMI $\geq 35 \mathrm{~kg} / \mathrm{m}^{2}$, presence of family history of PE, multiple pregnancy, fetal abnormalities, pre-conception diabetes, essential hypertension, renal, hepatic or cardiac diseases. Patients maintained on immunomodulatory drugs, had immune deficiency states, or autoimmune diseases were also excluded from the study. Preliminary examination conducted at $1^{\text {st }}$ visit included estimation of systolic and diastolic blood pressures (SBP \& DBP) to assure for being normotensive.

Throughout the antenatal visits, women who developed PE diagnostic criteria were grouped as PE group. PE was diagnosed by the development of gestational hypertension after the $12^{\text {th }}$ week GA in women who were normotensive at time of $1^{\text {st }}$ antenatal visit with SBP $\geq 140 \mathrm{mmHg}$ and/or DBP $\geq 90 \mathrm{mmHg}$ on at least two occasions, 4 hours apart, and proteinuria (one dipstick measurement $\geq 2+$ on a voided random urine sample) ${ }^{(16,17)}$. PE women were categorized according to time of development of PE into Early PE if diagnosed before the $20^{\text {th }}$ week GA and Late PE if diagnosed later to the $20^{\text {th }}$ week GA and within each group, PE was categorized as mild and severe. Severe PE was diagnosed according to the criteria published in the National High Blood Pressure Education Program Working Group Report on High Blood Pressure in Pregnancy ${ }^{(18)}$ including SBP $\geq 160 \mathrm{mmHg}, \mathrm{DBP} \geq 110 \mathrm{mmHg}$, and proteinuria $\geq 5 \mathrm{~g} /$ in a 24 -h period. The study also included a cross-matched number of pregnant women who completed their pregnancy free of manifestations of PE as control group. 


\section{Blood sampling:-}

At time of $1^{\text {st }}$ antenatal visit, all study participants gave $5 \mathrm{ml}$ blood sample that was withdrawn under complete aseptic conditions, allowed to clot and then centrifuged at $3000 \mathrm{rpm}$ for 10 minutes to separate serum that was collected in sterile Eppindorff tube and stores at $-80^{\circ} \mathrm{C}$ till be assayed. Blood samples were collected and numbered by an assistant who was blinded about diagnosis.

\section{Laboratory investigations:-}

1- Serum IL-10 was measured with an ELISA kit from Milenia ${ }^{\circledR}$, DPC Biermann, Bad Nauheim; Germany ${ }^{(19)}$.

2- Serum IL-6 ${ }^{(20)}$ and TNF- $\alpha^{(21)}$ levels were measured with an ELISA kit from Pelikine ${ }^{\mathrm{TM}}$ Inc., Concord, USA.

\section{Statistical analysis:-}

Obtained data were presented as mean $\pm \mathrm{SD}$, numbers and percentages. Results were analyzed using One-way ANOVA with post-hoc Tukey HSD Test and Chi-square test $\left(\mathrm{X}^{2}\right.$ test). Possible relationships were investigated using Pearson's linear regression. Sensitivity \& specificity of estimated parameters as predictors were evaluated using the receiver operating characteristic (ROC) curve analysis judged by the area under the curve (AUC) compared versus the null hypothesis that $\mathrm{AUC}=0.05$. Statistical analysis was conducted using the IBM SPSS (Version 23, 2015) for Windows statistical package. P value $<0.05$ was considered statistically significant.

\section{Results:-}

Seventy-nine primigravida developed PE during the observation period, 14 women were excluded and 65 women were collected as PE group. Another 65 primigravida who completed their pregnancy free of PE were collected as control group (Fig. 1). PE women had significantly higher body weight and BMI than control women, otherwise all enrolment data showed non-significant ( $p>0.05$ ) difference between both groups (Table 1).
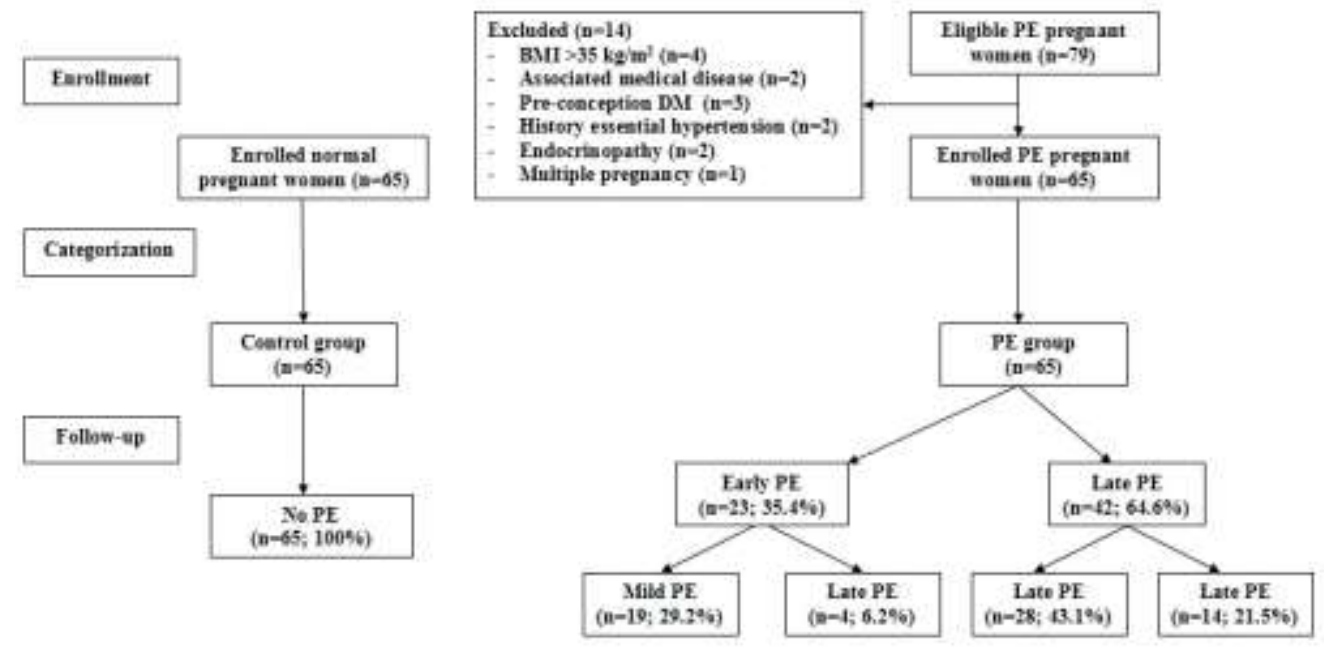

Fig. (1): Flow chart of the study

Table 1:- Baseline data of enrolled primigravida women determined at the $12^{\text {th }}$ week GA

\begin{tabular}{|l|l|l|l|l|}
\hline \multicolumn{2}{|l|}{ Data } & Control $(\mathrm{n}=65)$ & PE $(\mathrm{n}=65)$ & P value \\
\hline \multicolumn{2}{|l|}{ Age (years) } & $27.5 \pm 5.3$ & $26.2 \pm 6.1$ & 0.081 \\
\hline \multirow{3}{*}{ BMI data } & Weight $(\mathrm{kg})$ & $71.8 \pm 4.7$ & $76.6 \pm 7.6$ & $0.007 *$ \\
\cline { 2 - 5 } & Height $(\mathrm{cm})$ & $170 \pm 2$ & $169.4 \pm 2.5$ & 0.195 \\
\cline { 2 - 5 } & BMI $\left(\mathrm{kg} / \mathrm{m}^{2}\right)$ & $24.9 \pm 1.8$ & $26.7 \pm 2.8$ & $0.002^{*}$ \\
\hline \multirow{3}{*}{ blood pressure $(\mathrm{mmHg})$} & Systolic & $118.2 \pm 3.8$ & $118 \pm 4.6$ & 0.735 \\
\cline { 2 - 5 } & Diastolic & $82.5 \pm 4.3$ & $83.6 \pm 3.1$ & 0.225 \\
\hline \multirow{2}{*}{ Proteinuria $;$} & No & $42(64.6 \%)$ & $46(70.8 \%)$ & 0.453 \\
\cline { 2 - 5 } & Present (+) & $23(35.4 \%)$ & $19(29.2 \%)$ & \\
\hline
\end{tabular}


Data are presented as mean \pm SD \& numbers; percentages are in parenthesis; BMI: Body mass index; p>0.05: indicates non-significant difference; + : Level of protein in urine as judged by dipstick measurement and expressed as number of + marks

Among PE women, 23 women developed early PE; 19 had mild and 4 had severe PE. The other 42 women developed late PE; 28 had mild and 14 had severe PE. Women who developed mild early PE had significantly higher SBP $(p=0.002)$, DBP $(p=0.020)$ and extent of proteinuria $(p=0.025)$ compared to those who developed late mild PE. Similarly, women who developed severe early PE showed significantly $(\mathrm{p}=0.038)$ higher SBP measures, but showed non-significantly higher DBP $(\mathrm{p}=0.694)$ and extent of proteinuria $(\mathrm{p}=0.762)$ compared to those had severe late PE. Moreover, total women who developed early PE showed non-significantly higher measures than those who had late PE. Details of clinical findings at time of development of PE are shown in table 2.

Table 2:- Clinical data of PE women determined at time of development of PE

\begin{tabular}{|l|l|l|l|l|}
\hline \multicolumn{2}{|l|}{ Data } & Mild PE $(\mathrm{n}=47)$ & Severe PE $(\mathrm{n}=18)$ & Total \\
\hline \multirow{4}{*}{ SBP $(\mathrm{mmHg})$} & Early PE $(\mathrm{n}=23)$ & $151.4 \pm 2.8$ & $172.5 \pm 3.1$ & $155.1 \pm 8.6$ \\
\cline { 2 - 5 } & Late PE $(\mathrm{n}=42)$ & $144 \pm 2.6$ & $167.8 \pm 3.8$ & $152.5 \pm 11.3$ \\
\cline { 2 - 5 } & $\mathrm{P}=$ & 0.002 & 0.038 & 0.336 \\
\hline \multirow{4}{*}{ DBP $(\mathrm{mmHg})$} & Early PE $(\mathrm{n}=23)$ & $95.8 \pm 2.5$ & $115 \pm 4.1$ & $102.5 \pm 7.9$ \\
\cline { 2 - 5 } & Late PE $(\mathrm{n}=42)$ & $93.8 \pm 1.4$ & $114.4 \pm 1.8$ & $99.7 \pm 8.2$ \\
\cline { 2 - 5 } & $\mathrm{P}=$ & 0.020 & 0.694 & 0.543 \\
\hline \multirow{5}{*}{ Proteinuria +} & Early PE $(\mathrm{n}=23)$ & $2.5 \pm 0.5$ & $3.7 \pm 0.5$ & $2.7 \pm 0.6$ \\
\cline { 2 - 5 } & Late PE $(\mathrm{n}=42)$ & $2.3 \pm 0.4$ & $3.6 \pm 0.5$ & $2.5 \pm 0.6$ \\
\cline { 2 - 5 } & $\mathrm{P}=$ & 0.025 & 0.762 & 0.075 \\
\hline
\end{tabular}

Data are presented as mean \pm SD \& numbers; percentages are in parenthesis; PE: Pre-eclampsia; SBP: Systolic blood pressure; DBP: Diastolic blood pressure; P: significance versus women developed late PE; p<0.05: indicates significant difference; $p>0.05$ : indicates non-significant difference; $\$$ : Level of protein in urine as judged by dipstick measurement and expressed as number of + marks

Mean serum TNF- $\alpha(3.1 \pm 0.95 \mathrm{pg} / \mathrm{ml})$ and IL-6 $(33.9 \pm 12.9 \mathrm{pg} / \mathrm{ml})$ levels in PE women were significantly ( $\mathrm{p}=0.001)$ higher compared to control women $(2.55 \pm 0.7 \mathrm{pg} / \mathrm{ml} \& 13.3 \pm 5.6 \mathrm{pg} / \mathrm{ml}$, respectively). On contrary, serum IL-10 $(15.5 \pm 4.8 \mathrm{pg} / \mathrm{ml})$ levels in PE women were significantly $(\mathrm{p}=0.001)$ lower compared to control women $(22.7 \pm 11.6$ $\mathrm{pg} / \mathrm{ml})$, with significantly $(\mathrm{p}=0.001)$ higher IL-6/IL-10 ratio in PE women $(2.39 \pm 1.14)$ compared to control women (0.77 \pm 0.56$)$, (Fig. $2 \& 3$ ).

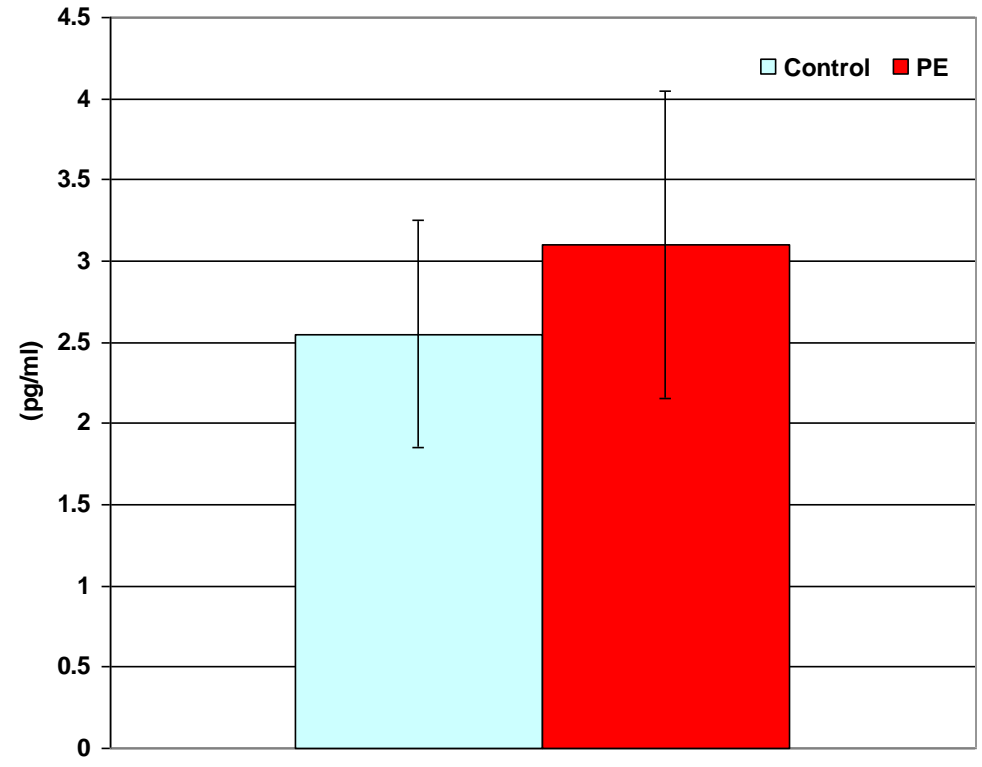

Fig. (2): Mean ( $($ SD) serum TNF-alpha levels estimated at the 12th wk GA in women of both groups 


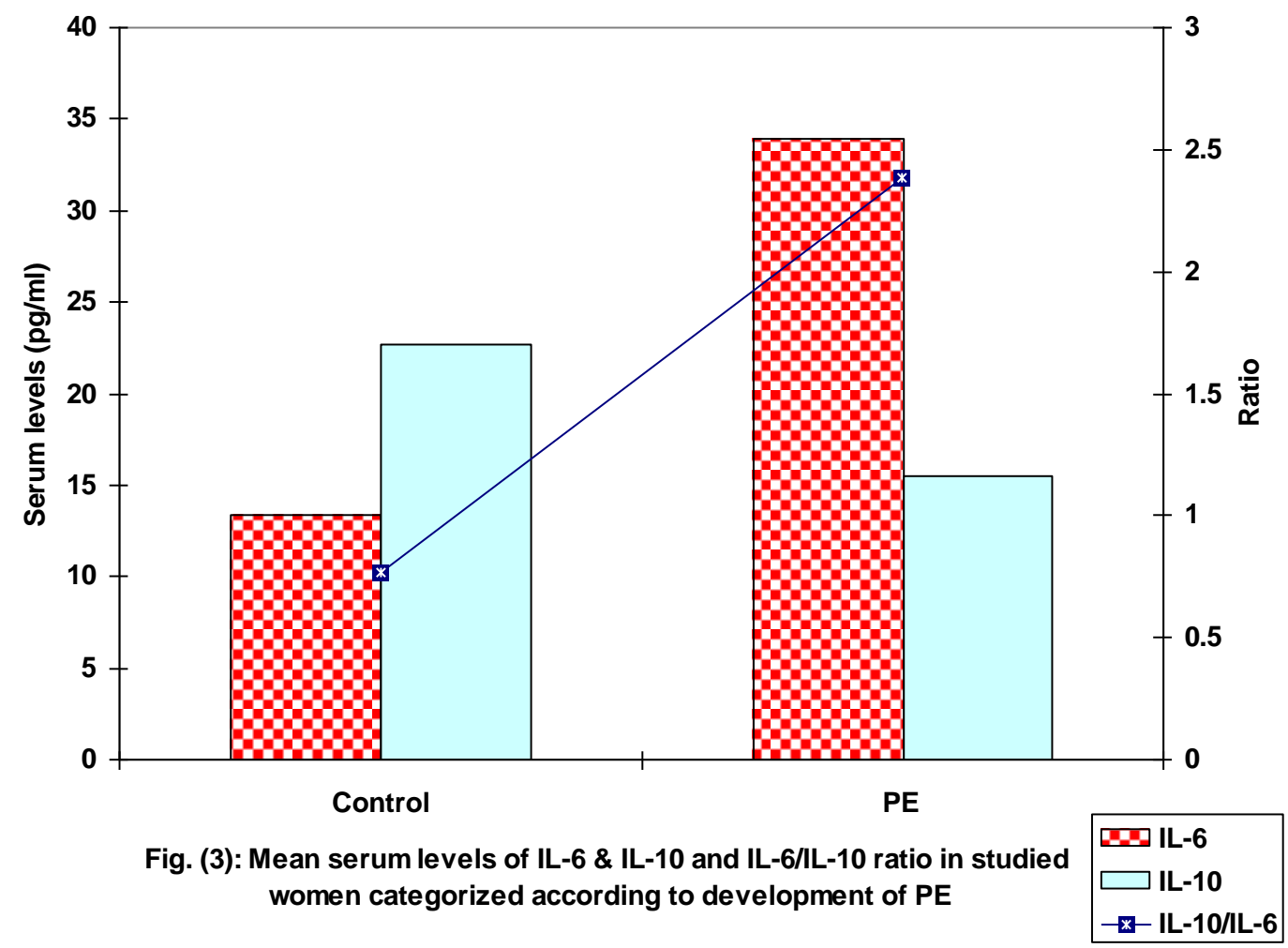

Pearson's correlation analysis showed positive significant correlation between development of PE and body weight, BMI, serum levels of TNF- $\alpha$, IL-6 and IL-6/IL-10 ratio, while showed negative significant correlation with serum IL-10. PE severity, as judged by blood pressure measures at time of PE diagnosis, showed positive significant correlation with maternal age, body weight, BMI, and estimated serum parameters (Table 3).

Table 3:- Pearson's correlation between demographic data and laboratory findings in studied women

\begin{tabular}{|l|l|l|l|l|}
\hline \multirow{2}{*}{ Variables } & Development of PE & \multicolumn{3}{l|}{ Severity of PE } \\
\cline { 2 - 5 } & $\mathrm{r}$ & $\mathrm{p}$ & $\mathrm{r}$ & $\mathrm{p}$ \\
\hline Age (years) & -0.114 & $>0.05$ & 0.379 & 0.002 \\
\hline Body weight $(\mathrm{kg})$ & 0.345 & $<0.001$ & 0.273 & 0.028 \\
\hline BMI & 0.370 & $<0.001$ & 0.270 & 0.030 \\
\hline SBP & 0.108 & $>0.05$ & 0.153 & $>0.05$ \\
\hline DBP & 0.148 & $>0.05$ & 0.187 & $>0.05$ \\
\hline TNF- $\alpha$ & 0.314 & $<0.001$ & 0.360 & 0.003 \\
\hline IL-10 & -0.379 & $<0.001$ & -0.302 & 0.014 \\
\hline IL6 & 0.722 & $<0.001$ & 0.433 & 0.001 \\
\hline IL-10/IL6 & 0.673 & $<0.001$ & 0.461 & $<0.001$ \\
\hline
\end{tabular}

r: Pearson's correlation coefficient, BMI: Body mass index; SBP: Systolic blood pressure; DBP: Diastolic blood pressure; TNF- $\alpha$ : Tumor necrosis factor- $\alpha$; IL: Interleukin; $p$ value $<0.05$ indicates significance

ROC curve analysis defined high body weight, BMI, high serum IL-6 and TNF- $\alpha$ and high IL-6/IL-10 ratio as significant specific predictor, while low serum IL-10 as a significant sensitive predictor for possibility of development of PE (Fig. 4). Also, ROC curve analysis defined high IL-6/IL-10 ratio as significant sensitive predictor for severe PE (Table 4), while defined high serum IL-6 (AUC=0.838, $\mathrm{p}=0.024$ ) and high TNF- $\alpha$ (AUC $=0.846, p=0.021$ ) as significant specific predictors for mild PE (Fig. 5). 
Table (4):- ROC curve analysis of demographic data and laboratory findings in studied women as early predictors for later development of PE

\begin{tabular}{|l|l|l|l|l|l|l|}
\hline \multirow{2}{*}{} & Development of PE & \multicolumn{2}{l|}{ Severity of PE } \\
\cline { 2 - 7 } & AUC & $\mathrm{p}$ & $95 \%$ CI & AUC & $\mathrm{p}$ & $95 \%$ CI \\
\hline Age $($ years $)$ & $0.404( \pm 0.051)$ & $>0.05$ & $0.304-0.504$ & $0.313( \pm 0.141)$ & $>0.05$ & $0.038-0.589$ \\
\hline BW $(\mathrm{kg})$ & $0.699( \pm 0.046)$ & $<0.001$ & $0.608-0.789$ & $0.548( \pm 0.102)$ & $>0.05$ & $0.347-0.749$ \\
\hline BMI & $0.713( \pm 0.045)$ & $<0.001$ & $0.624-0.802$ & $0.433( \pm 0.137)$ & $>0.05$ & $0.163-0.702$ \\
\hline SBP & $0.492( \pm 0.052)$ & $>0.05$ & $0.390-0.593$ & $0.774( \pm 0.110)$ & $>0.05$ & $0.558-0.989$ \\
\hline DBP & $0.541( \pm 0.051)$ & $>0.05$ & $0.440-0.642$ & $0.381( \pm 0.085)$ & $>0.05$ & $0.215-0.547$ \\
\hline TNF- $\alpha$ & $0.687( \pm 0.047)$ & $<0.001$ & $0.594-0.780$ & $0.234( \pm 0.064)$ & $>0.05$ & $0.109-0.359$ \\
\hline IL-10 & $0.328( \pm 0.047)$ & $=0.001$ & $0.236-0.421$ & $0.167( \pm 0.113)$ & $>0.05$ & $0.055-0.388$ \\
\hline IL6 & $0.923( \pm 0.023)$ & $<0.001$ & $0.877-0.968$ & $0.131( \pm 0.079)$ & $>0.05$ & $0.019-0.051$ \\
\hline IL-10/IL6 & $0.916( \pm 0.023)$ & $<0.001$ & $0.872-0.961$ & $-0.016( \pm 0.018)$ & 0.020 & $0.024-0.286$ \\
\hline
\end{tabular}

AUC: Area under curve, CI: Confidence interval; BW: Body weight; BMI: Body mass index; SBP: Systolic blood pressure; DBP: Diastolic blood pressure; TNF- $\alpha$ : Tumor necrosis factor- $\alpha$; IL: Interleukin; $p$ value $<0.05$ indicates significance

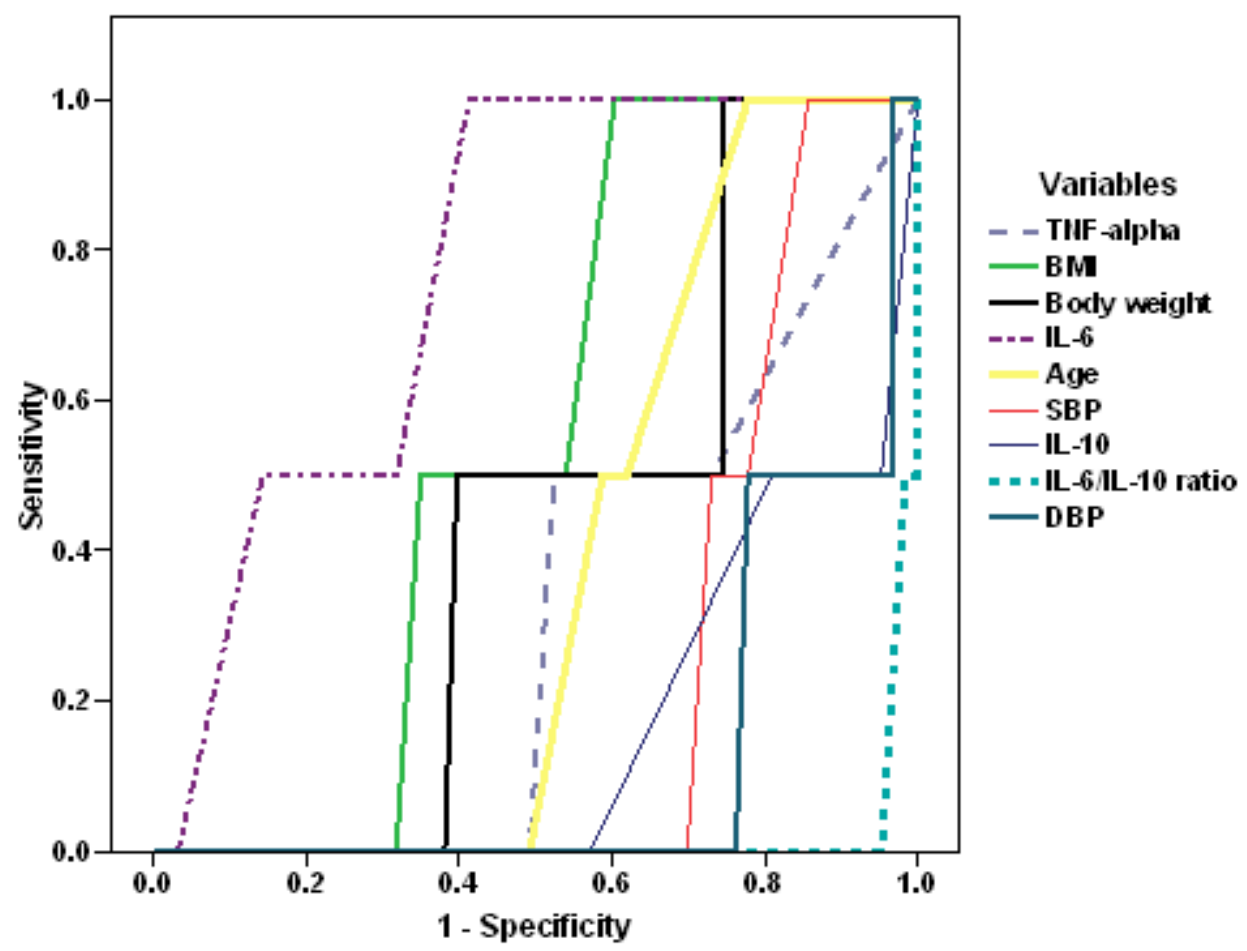

Fig. 4:- ROC curve analysis for predictors of severe PE among PE women 


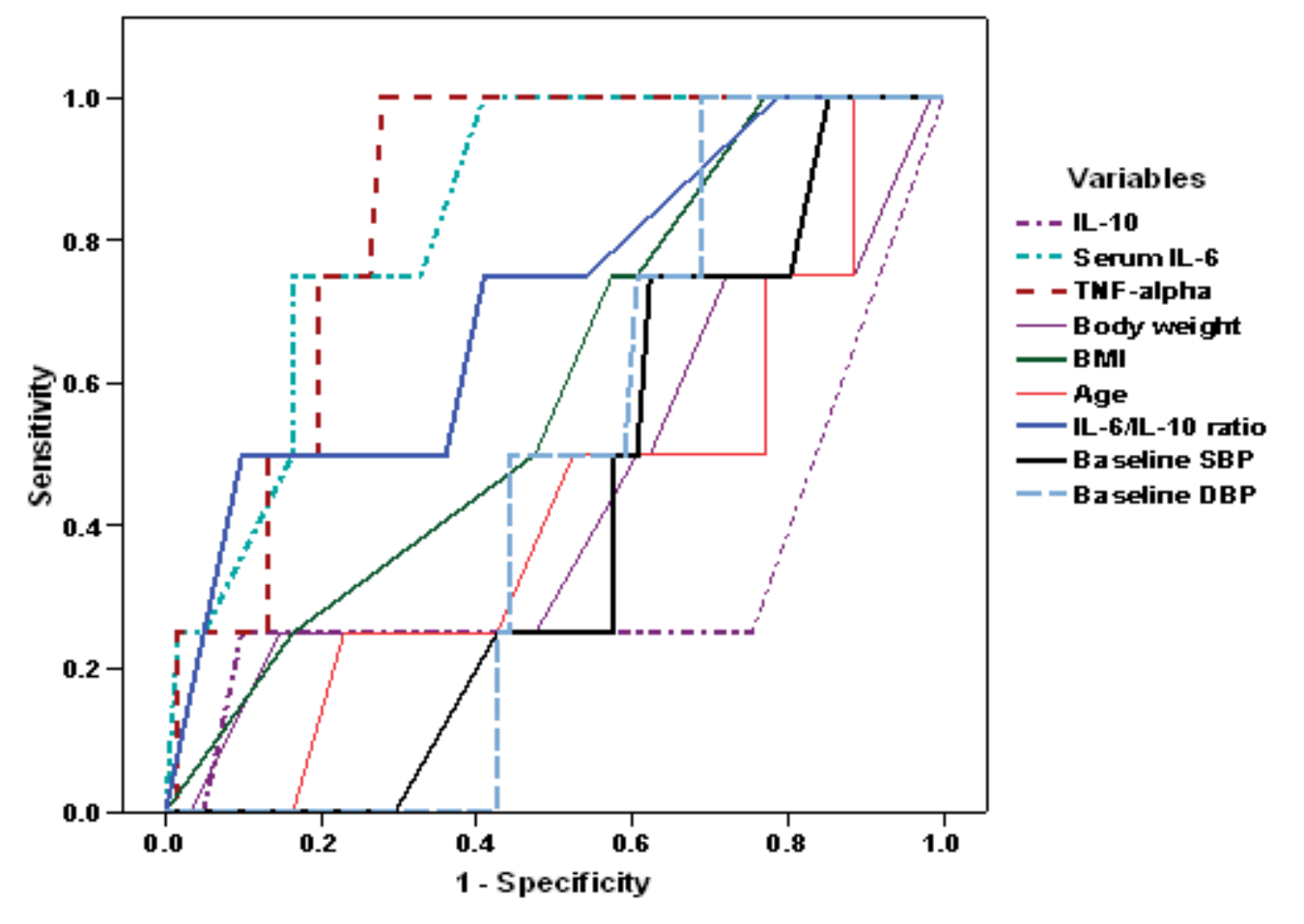

Fig. 5:- ROC curve analysis for predictors of mild PE among PE women

\section{Discussion:-}

The current study detected significant alteration of body immune response in pregnant PE women than women who completed their pregnancy course free of hypertensive manifestations (Control women). Such alteration shifted immune response of PE pregnant women towards the pro-inflammatory side as manifested by significantly higher serum levels of pro-inflammatory cytokines; TNF- $\alpha$ and IL-6 associated with significantly lower serum levels of anti-inflammatory cytokine; IL-10.

These findings go in hand with multiple previous studies evaluated the relation between development of PE and altered immune milieu; where Vargas-Rojas et al. ${ }^{(22)}$ suggested that disturbed cytokine balance during PE encourage development of an exacerbated inflammatory response with a shift towards a pro-inflammatory status. Also, Cornelius et al. ${ }^{(23)}$ experimentally found on transfer of Th17 cells resulting from reduced uterine perfusion in induced tissue oxidative stress, increased serum IL-6 and causes increased blood pressure and intrauterine growth restriction and concluded that autoimmune status associated with Th17 cells may have a role in pathogenesis of PE. Thereafter, Zhang et al. ${ }^{(24)}$ found plasma concentrations of IL-17 and IL-22 were significantly increased along with a decreased plasma IL-10 concentration in severe PE patients and Ribeiro et al. ${ }^{(25)}$ found plasma levels of IL-6, IL17 and TNF- $\alpha$ were significantly higher whereas IL-10 levels were significantly lower in PE than in normotensive women. Also, Poordast et al. ${ }^{(26)}$ detected low serum IL-21, anti-inflammatory cytokine and significantly increased serum levels of IL-17 and TGF- $\beta$, pro-inflammatory cytokines in PE than normal pregnant women. Recently, Xu et al. ${ }^{(27)}$ found trophoblasts from PE placentas produced significantly more TNF- $\alpha$, IL-6 and IL-8, but significantly less IL-10 than trophoblasts from normal control placentas.

Interestingly, these alterations of immune milieu were detected early in pregnancy at the $12^{\text {th }}$ wk GA with concomitant blood pressure measures within normal range and with non-significant difference between women of both groups. Moreover, these altered serum levels appeared prior to appearance of any manifestations for PE; a finding indicating a role for these alterations in pathogenesis of PE, illustrating the impact of pregnancy on immune system and suggesting a reciprocal effect. 
In support of this assumption, blood pressure measures determined at time of development of PE showed significant correlation with serum levels of cytokines estimated at the $12^{\text {th }}$ wk GA and such correlation was positive with proinflammatory, while was negative with the anti-inflammatory cytokines. These correlations go in hand with Zhang et al. ${ }^{(24)}$ who detected a positive correlation between plasma IL-22 concentration and the percentage of Th22 cells and severe PE patients and data obtained by Poordast et al. ${ }^{(26)}$ support the rational of imbalance of cytokine profile in PE patients.

Statistical analyses defined high serum IL-6 and low IL-10 levels manifested as high IL-6/IL-10 ratio is the significant early predictor for later development of PE. Similarly, Salazar-Garcia et al. ${ }^{(28)}$ found PE patients had significantly higher TNF $/$ /IL-10 cell ratio and Th17/Treg cell ratio compared to patients without PE.

Also, ROC curve analysis defined high IL-6/IL-10 as significant predictor for severe, while high IL-6 and TNF- $\alpha$ levels as significant predictors for mild PE, thus indicating the diagnostic role of immune disturbance for types of PE. Similarly, Ribeiro et al. ${ }^{(25)}$ found elevated plasma levels of IL-6, IL-17 and TNF- $\alpha$ with decreased plasma levels of IL-10 can differentiate between early-onset and late-onset PE, while Daneva et al. ${ }^{(29)}$ reported that in pregnancies complicated by PE there are increased levels of proinflammatory cytokines and changes are most pronounced in mild PE, while changes in anti-inflammatory cytokines are more pronounced in severe PE.

In trial to explore the pathogenetic basis for the relationship between disturbed immune response and development of PE, Wang et al. ${ }^{(30)}$ found dendritic cells (DCs) derived from PE patients expressed significantly higher levels of CD80, 83 and 86 with significantly higher secretion of IL-23 and a stronger ability to promote the differentiation of CD4+ T cells into Th1/Th17 cells when cultured with different cytokines than DCs derived from healthy pregnant women, so concluded that altered phenotypes and functions of DCs may promote the abnormal balance of Th1 and Th17 resulting in the development of PE.

Moreover, Kemse et al. ${ }^{(31)}$ supposed a role for micronutrient deficiency for development of pregnancy-induced hypertension (PIH) and experimentally found PIH induction increased the mRNA levels of IL-6, while lowering the placental anti- inflammatory cytokine IL-10 and the combined supplementation of folic acid, vitamin $\mathrm{B}_{12}$ and omega-3 fatty acids improved placental IL-10 levels and decreased TNF- $\alpha$ levels, while, Fan et al. ${ }^{(32)}$ found the AA genotype, compared to the $\mathrm{CC}$ and $\mathrm{AC}+\mathrm{CC}$ genotypes of IL-10-592A/C correlate with elevated risk of developing PE.

Recently, Scroggins et al. ${ }^{(33)}$ experimentally found arginine vasopressin (AVP) infusion throughout gestation in mice increased pro-inflammatory cytokines in maternal plasma, amniotic fluid, and placenta, but decreased antiinflammatory cytokines and found mouse and human $\mathrm{T}$ cells expressed all receptors for AVP, so documented a potential role for AVP in initiating immune dysfunction typical of PE.

\section{Conclusion:-}

Pre-eclampsia was associated with shift of immune response to pregnancy towards production of pro-inflammatory cytokines. The detected early disturbance of immune milieu points to its role in pathogenesis of PE. High IL-6/IL-10 ratio early in pregnancy could predict later development of PE especially severe PE. High IL-6 and TNF- $\alpha$ serum levels could early predict the development of mild PE. 


\section{References:-}

1. Jeyabalan A: Epidemiology of preeclampsia: impact of obesity. Nutr Rev. 2013; 71 Suppl 1:S18-25.

2. Phipps E, Prasanna D, Brima W, Jim B: Preeclampsia: Updates in Pathogenesis, Definitions, and Guidelines. Clin J Am Soc Nephrol. 2016; 11(6):1102-13.

3. Ahmed A, Rezai H, Broadway-Stringer S: Evidence-Based Revised View of the Pathophysiology of Preeclampsia. Adv Exp Med Biol. 2017;956:355-374.

4. Smith TA, Kirkpatrick DR, Kovilam O, Agrawal DK: Immunomodulatory role of vitamin D in the pathogenesis of preeclampsia. Expert Rev Clin Immunol. 2015; 11(9):1055-63.

5. Cheng SB, Sharma S: Interleukin-10: a pleiotropic regulator in pregnancy. Am J Reprod Immunol. 2015; 73(6):487-500.

6. Laresgoiti-Servitje E: A leading role for the immune system in the pathophysiology of preeclampsia. J Leukoc Biol. 2013; 94(2):247-57.

7. Cardaropoli S, Rolfo A, Todros T: Helicobacter pylori and pregnancy-related disorders. World J Gastroenterol. 2014; 20(3):654-64.

8. Konečná B, Vlková B, Celec P: Role of fetal DNA in preeclampsia (review). Int J Mol Med. 2015; 35(2):299304.

9. Cray C, Zaias J, Altman NH: Acute phase response in animals: a review. Comp Med., 2009; 59(6): 517-26.

10. Kraj P, Ignatowicz L: The mechanisms shaping the repertoire of CD4+ Foxp3+ regulatory $\mathrm{T}$ cells. Immunology. 2018 Mar; 153(3):290-296.

11. Ng SC, Gilman-Sachs A, Thaker P, Beaman KD, Beer AE, Kwak-Kim J: Expression of intracellular Th1 and Th2 cytokines in women with recurrent spontaneous abortion, implantation failures after IVF/ET or normal pregnancy. Am J Reprod Immunol. 2002; 48(2):77-86.

12. Pinheiro MB, Gomes KB, Ronda CR, Guimarães GG, Freitas LG, Teixeira-Carvalho A, Martins-Filho OA, Dusse LM: Severe preeclampsia: association of genes polymorphisms and maternal cytokines production in Brazilian population. Cytokine. 2015; 71(2):232-7.

13. Wang J, Su L, Zhu T: [Effect of dendritic cells on the differentiation of Th1/Th17 in peripheral blood from preeclampsia patients]. Xi Bao Yu Fen Zi Mian Yi Xue Za Zhi. 2013 Jul;29(7):744-7.

14. Schumacher A, Brachwitz N, Sohr S, Engeland K, Langwisch S, Dolaptchieva M, Alexander T, Taran A, Malfertheiner SF, Costa SD, Zimmermann G, Nitschke C, Volk HD, Alexander H, Gunzer M, Zenclussen AC: Human chorionic gonadotropin attracts regulatory $\mathrm{T}$ cells into the fetal-maternal interface during early human pregnancy. J Immunol. 2009; 182(9):5488-97.

15. Duan H, Zhao G, Xu B, Hu S, Li J: Maternal Serum PLGF, PAPPA, $\beta$-hCG and AFP Levels in Early Second Trimester as Predictors of Preeclampsia. Clin Lab. 2017 May 1;63(5):921-925.

16. Gifford RW, August PA, Cunningham FG: Report of the national high blood pressure working group on research on hypertension in pregnancy. Am. J Obstet. Gynecol., 2000; 183:S1-22.

17. Lenfant C; National Education Program Working Group on High Blood Pressure in Pregnancy: Working group report on high blood pressure in pregnancy. J Clin Hypertens (Greenwich). 2001; 3(2):75-88.

18. ACOG. Practice Bulletin No. 33: Diagnosis and management of preeclampsia and eclampsia. Obstetrics and Gynecology, 2002; 99: 159-67

19. Poll T: IL-10 release during endotoxaemia in chimpanzees: role of platelet-activating factor and IL-6. Scand. J Immunol. 1996; 43: 122

20. Gaines-Das RE, Poole S: The international standard for interleukin-6-evaluation in an international collaborative study. J Immunol Methods. 1993; 160: 147-53.

21. De Kossodo S, Houba V, Grau GE: the WHO Collaborative Study Group. Assaying tumor necrosis factor concentrations in human serum. A WHO international collaborative study. J Immunol Methods. 1995; 182:10714.

22. Vargas-Rojas MI, Solleiro-Villavicencio H, Soto-Vega E: Th1, Th2, Th17 and Treg levels in umbilical cord blood in preeclampsia. J Matern Fetal Neonatal Med. 2016; 29(10):1642-5.

23. Cornelius DC, Amaral LM, Wallace K, Campbell N, Thomas AJ, Scott J, Herse F, Wallukat G, Dechend R, LaMarca B: Reduced uterine perfusion pressure T-helper 17 cells cause pathophysiology associated with preeclampsia during pregnancy. Am J Physiol Regul Integr Comp Physiol. 2016; 311(6):R1192-9.

24. Zhang Z, Liu H, Shi Y, Xu N, Wang Y, Li A, Song W: Increased circulating Th22 cells correlated with Th17 cells in patients with severe preeclampsia. Hypertens Pregnancy. 2017; 36(1):100-107.

25. Ribeiro VR, Romao-Veiga M, Romagnoli GG, Matias ML, Nunes PR, Borges VTM, Peracoli JC, Peracoli MTS: Association between cytokine profile and transcription factors produced by T-cell subsets in early- and late-onset pre-eclampsia. Immunology. 2017; 152(1):163-173. 
26. Poordast T, Najib FS, Baharlou R, Bijani A, Alamdarloo SM, Poordast A: Assessment of T helper 17associated cytokines in third trimester of pregnancy. Iran J Immunol. 2017; 14(2):172-179.

27. Xu J2, Gu Y, Sun J, Zhu H, Lewis DF, Wang Y: Reduced CD200 expression is associated with altered Th1/Th2 cytokine production in placental trophoblasts from preeclampsia. Am J Reprod Immunol. 2018; 79(1). doi: 10.1111/aji.12763.

28. Salazar Garcia MD, Mobley Y, Henson J, Davies M, Skariah A, Dambaeva S, Gilman-Sachs A, Beaman K, Lampley C, Kwak-Kim J: Early pregnancy immune biomarkers in peripheral blood may predict preeclampsia. J Reprod Immunol. 2018; 125:25-31.

29. Daneva AM, Hadži-Lega M, Stefanovic M: Correlation of the system of cytokines in moderate and severe preeclampsia. Clin Exp Obstet Gynecol. 2016;43(2):220-4.

30. Wang J, Tao YM, Cheng XY, Zhu TF, Chen ZF, Yao H, Su LX: Dendritic cells derived from preeclampsia patients influence Th1/Th17 cell differentiation in vitro. Int J Clin Exp Med. 2014; 7(12):5303-9

31. Kemse N, Sundrani D, Kale A, Joshi S: Maternal Micronutrients, Omega-3 Fatty Acids and Gene Expression of Angiogenic and Inflammatory Markers in Pregnancy Induced Hypertension Rats. Arch Med Res. 2017; 48(5):414-422.

32. Fan DM, Wang Y, Liu XL, Zhang A, Xu Q: Polymorphisms in interleukin-6 and interleukin-10 may be associated with risk of preeclampsia. Genet Mol Res. 2017;16(1).

33. Scroggins SM, Santillan DA, Lund JM, Sandgren JA, Krotz LK, Hamilton WS, Devor EJ, Davis HA, Pierce GL, Gibson-Corley KN, Sigmund CD, Grobe JL, Santillan MK: Elevated Vasopressin in Pregnant Mice Induces T Helper Subset Alterations Consistent with Human Preeclampsia. Clin Sci (Lond). 2018 Jan 25. pii: CS20171059. doi: 10.1042/CS20171059. [Epub ahead of print] 